\title{
EVALUASI KEPUASAN PENGGUNA E-LEARNING PADA PROSES PEMBELAJARAN DARING DI INSTITUT MANAJEMEN WIYATA INDONESIA
}

\author{
Eneng Fitri Handayani \\ Program Studi Administrasi Bisnis, Institut Manajemen Wiyata Indonesia \\ enengfitri98@gmail.com \\ Mariati Tirta Wiyata \\ Program Studi Administrasi Bisnis, Institut Manajemen Wiyata Indonesia \\ mariati.tirtawiyata@imwi.ac.id
}

\begin{abstract}
ABSTRAK
Penelitian ini bertujuan untuk memperoleh gambaran tentang (1) kualitas sistem, (2) kualitas informasi, (3) kualitas layanan, dan (4) kepuasan pengguna E-learning pada proses pembelajaran daring di Institut Manajemen Wiyata Indonesia. Penelitian ini menggunakan metode deskriptif evaluatif rata-rata tertimbang. Sampel penelitian ini diambil dengan teknik purposive sampling yaitu 100 mahasiswa. Pengumpulan data dilaksanakan dengan menyebarkan kuesioner. Hasil penelitian menunjukkan: (1) kualitas sistem E-learning pada proses pembelajaran daring dikategorikan (baik), (2) kualitas informasi E-learning pada proses pembelajaran daring dikategorikan (baik), (3) kualitas layanan E-learning pada proses pembelajaran daring dikategorikan kurang baik, dan (4) kepuasan pengguna E-learning pada proses pembelajaran daring dikategorikan baik.
\end{abstract}

Kata Kunci: E-learning, Kualitas Sistem, Kualitas Informasi, Layanan, Kepuasan.

\begin{abstract}
The research aims to obtain an overview of the (1) The quality of e-learning systems, (2) The quality of $e$ learning information, (3) The quality of e-learning services, and (4) e-Learning user satisfaction in the online learning process at the Institut Manajemen Wiyata Indonesia. This research uses the descriptive method of weighted average evaluative. Data collection is implemented by spreading the questionnaire. The results showed: (1) The quality of E-learning systems in the online learning process is categorized (well), (2) The quality of E-learning information on the online learning process is categorized (well), (3) The quality of E-learning services on the category of online learning is not good, (4) The satisfaction of E-learning users in the online learning process is categorized well.
\end{abstract}

Keywords: E-Learning, System Quality, Information Quality, Service Quality, User Satisfaction.

\section{PENDAHULUAN}

Indonesia merupakan salah satu negara berkembang di dunia dengan pengaruh teknologi yang cukup besar. Saat ini perkembangan Teknologi Informasi dan Komunikasi (TIK) mengalami perkembangan yang sangat pesat. Meningkatnya perkembangan teknologi yang semakin pesat ini, dikarenakan kuatnya era globalisasi yang mana internet dan komputer merupakan hal yang mendominasi berbagai aktivitas kehidupan. Salah satunya membuat teknologi berdampak terhadap berbagai bidang. Teknologi Informasi dan Komunikasi dapat mengubah pola masyarakat dalam mencari dan mendapatkan informasi yang tidak terbatas pada informasi yang diinginkan.

Salah satu bidang yang mengalami perkembangan TIK adalah bidang pendidikan. Seperti halnya kondisi pandemi COVID 19 saat ini yang kian mengancam yang mengharuskan peserta didik dan dosen melakukan kegiatan belajar mengajar di rumah masing-masing dengan mengakses website yang telah disiapkan oleh lembaga pendidikan. Pemanfaatan TIK dalam dunia pendidikan memiliki kelebihan dari segi efektivitas dan fleksibilitas. Efektif dapat dilihat dari berbagai sumber belajar yang dapat dijangkau peserta didik, dan fleksibel karena tidak memiliki keterbatasan waktu dan ruang, jadi bisa kapan saja dan di mana saja. Bentuk perkembangan teknologi informasi yang dapat dimanfaatkan sebagai media pembelajaran yaitu sistem E-learning. Pembelajaran E-learning merupakan inovasi yang dapat dimanfaatkan dalam proses pembelajaran, tidak hanya dalam penyampaian materi. 
Sebagai lembaga pendidikan, Institut Manajemen Wiyata Indonesia terus berupaya untuk meningkatkan kualitas pembelajaran (Wiyata \& Awaliah, 2019), dan turut terjun dalam pemanfaatan TIK dalam bentuk E-Learning. Berawal dari kondisi pandemi COVID 19 yang terus meluas dan sebagai upaya pencegahan, serta mematuhi imbuan pemerintah yang berharap masyarakat dapat memanfaatkan kebijakan Kementerian Pendidikan dan Kebudayaan (Kemendikbud) dalam program belajar di rumah dengan memanfaatkan sistem E-Learning yang disediakan oleh lembaga pendidikan masing-masing. Lingkungan Kampus Institut Manajemen Wiyata Indonesia (IMWI) telah menerapkan pembelajaran menggunakan E-learning Management System (LMS) sejak awal Maret 2020 pada saat memasuki Semester Genap Tahun Akademik 2019/2020. Sistem tersebut dimuat dalam halaman website elearning.imwi.ac.id, pada sistem LMS dengan memuat menu-menu yang dapat memudahkan mahasiswa dalam pembelajaran, termasuk di dalamnya telah tersedia menu untuk quiz dan ujian.

Penelitian ini bertujuan untuk memperoleh gambaran bagaimana kualitas sistem, kualitas informasi, kualitas layanan, dan kepuasan pengguna E-Learning yang disediakan oleh Kampus IMWI. Penelitian oleh Purwandari (2016) menemukan bahwa pembelajaran menggunakan sistem E-learning dapat berhasil efektif, memudahkan peserta didik dalam mengakses materi, dan berdiskusi dalam forum yang disediakan. Pembelajaran berbasis E-Learning tidak dapat berlangsung begitu saja tanpa adanya kesiapan operator. Kesiapan lainnya adalah dukungan oleh peserta didik, dosen, dan sarana prasarana.

\section{LANDASAN TEORI \\ E-learning \\ Pengertian E-learning}

E-learning merupakan inovasi yang dimanfaatkan dalam proses pembelajaran dan berbasis elektronik dalam mendukung usaha-usaha pengajaran melalui teknologi internet. Dengan demikian E-Learning ini lebih tepat ditujukan sebagai usaha untuk membuat proses belajar yang ada di suatu lembaga pendidikan ke dalam bentuk digital (Binus, 2019).

\section{Komponen E-learning}

Dalam penelitian oleh Aidah (2019), komponen-komponen E-Learning dijelaskan sebagai berikut:

a) Infrastruktur E-learning: dapat berupa personal computer, HP, Android, jaringan komputer dan perlengkapan multimedia

b) Sistem dan aplikasi E-learning: sistem perangkat lunak yang memvirtualisasi proses belajar mengajar konvesional.

c) Konten E-Learning: konten bahan ajar

\section{Manfaat E-Learning}

Pemanfaatan E-learning yang baik akan membawa hasil yang maksimal. Kehadiran E-learning: (1) dapat mempersingkat waktu dan meminalisir biaya, (2) dapat dengan mudah mengakses materi, (3) dapat saling bertukar informasi dan dapat mengakses bahan materi secara berulang-ulang, (4) proses pengembangan pengetahuan tidak hanya terjadi dalam ruangan saja, tetapi dengan bantuan jaringan komputer (Hartanto, 2016).

Dengan demikian penerapan E-learning di perguruan tinggi diharapkan dapat memberikan manfaat diantaranya: (1) mahasiswa aktif dalam berinteraksi satu dengan lainnya bahkan dengan dosennya, (2) tersedianya sumber-sunber pembelajaran yang tak terbatas, (3) dapat meningkatkan kualitas lulusan dan perguruan tinggi.

\section{Model Kesuksesan Sistem Informasi}

Dari sekian banyak penelitian yang telah dilakukan, faktor yang sering digunakan untuk kesuksesan sistem informai salah satunya adalah menurut DeLone dan McLean (1992). Model yang dikembangkan oleh DeLone dan McLean cepat mendapat tanggapan karena model tersebut sederhana, valid, dan memang sangat dibutuhkan untuk menjadi acuan dalam membuat sistem informasi yang akan diterapkan. Berdasarkan teori-teori dan hasil-hasil penelitian sebelumnya yang telah dikaji, DeLone dan McLean pada tahun 1992 mengembangkan suatu model kesuksesan sistem informasi (D\&M IS Succses Model) dan pada tahun (2003) DeLone dan McLean memperbaiki modelnya (Iivari, 2005; Urbach \& Müller, 2012). Berikut merupakan pengukuran-pengukuran model kesusksesan informasi Delone \& McLean (2003). 


\section{Indikator-indikator}

Berdasarkan model kesuksesan DeLone dan McLean terdapat beberapa variabel yang dapat untuk mengukur kesuksesan sistem informasi, di bawah ini merupakan indikator yang dapat digunakan dalam variabel-variabel tersebut:

\section{a) Kualitas Sistem}

Kualitas sistem biasanya berfokus pada karakteristik kinerja sistem tersebut (Delone \& McLean, 2003). Kualitas sistem dalam sistem informasi E-learning Kampus IMWI menyangkut keterkaitan fitur dalam sistem termasuk performa sistem dan user interface. Berikut merupakan indikator untuk mengukur kualitas sistem:

1) Kemudahan Penggunaan

Sistem informasi dikatatakan berkualitas jika sistem tersebut dirancang dengan tujuan untuk memudahkan pengguna dalam melakukan pembelajaran E-learning.

2) Kemudahan Dipelajari

Selain memudahkan pengguna, sistem informasi yang baik diharapkan mudah dipelajari, dipahami dan tidak memerlukan waktu yang lama dalam mempelajarinya.

3) Kecepatan Akses

Apabila kecepatan akses cepat, maka sistem tersebut memiliki kualitas yang baik.

4) Keandalan Sistem

Keandalan sistem di sini merupakan ketahanan yang dimiliki oleh sistem tersebut dari kerusakan dan kesalahan dalam artian tidak adanya masalah.

5) Fleksibilitas

Merupakan kemampuan sistem dalam melakukan perubahan sesuai yang diinginkan pengguna, sehingga pengguna merasa puas dengan sistem yang diberikan.

6) Kegunaan Fitur dan Fungsi Sistem

Dengan tersedianya fitur dan fungsi yang dapat memenuhi kebutuhan pengguna akan merasa lebih puas dengan sistem yang disediakan.

7) Keamanan

Sistem informasi dapat dikatakan baik jika keamanan sistem dapat diandalkan.

\section{b) Kualitas Informasi}

Delone \& McLean (2003) mengatakan bahwa kualitas informasi mengukur kualitas output dari sistem informasi, terutama dari bentuk laporan-laporan. Berikut indikator pengukuran kualitas Informasi:

1) Akurasi

Informasi yang akurat berarti bebas dari kesalahan. Dikatakan akurasi merupakan kebenaran dari sistem informasi.

2) Kelengkapan

Hal ini ditekankan pada kelengkapan isi dari sistem informasi, karena kelengkapan sistem mencakup kebutuhan penguna.

3) Format (Bentuk)

Format/bentuk penyajian sistem yang baik serta dapat dipahami pengguna merupakan format yang berkualitas.

4) Ketepatan Waktu

Kualitas informasi dapat dikatakan baik apabila yang dihasilkan outputnya tepat waktu. Karena apabila tidak tepat waktu akan berpengaruh dalam kecepatan dalam pengambilan keputusan.

5) Relevansi

Apabila informasi yang dihasilkan relevan, maka informasi tersebut akan berguna.

\section{c) Kualitas Layanan}

Merupakan kualitas dukungan yang didapatkan pengguna (dalam hal ini merupakan layanan dalam pembelajaran E-learning). Beberapa indikator kualitas layanan antara lain: responsiveness (kecepatan respon), technical competence (kemampuan teknik), dan empathy (empati).

\section{d) Kepuasan Pengguna}

Kepuasan pengguna merupakan respon dan umpan balik yang dirasakan pengguna setelah melakukan pembelajaran secara E-learning. Berikut merupakan indikator pengukuran kepuasan pengguna:

1) Efisiensi

2) Keefektifan

3) Kepuasan pengguna 


\section{METODE PENELITIAN}

Penelitian ini merupakan penelitian evaluasi dengan menggunakan pendekatan kuantitatif dan dilaksanakan di Kampus Institut Manajemen Wiyata Indonesia (IMWI) yang beralamatkan di Jalan Gudang Nomor 7-9, Kelurahan Kebondjati, Kecamatan Cikole, Kota Sukabumi, Jawa Barat. Subjek penelitian ini yaitu 100 (seratus) orang mahasiswa IMWI yang mengikuti proses pembelajaran daring.

Penelitian ini menggunakan kuesioner yang telah divalidasi untuk mengukur indikator komponen kualitas sistem, kualitas informasi, kualitas layanan, dan kepuasan pengguna E-Learning pada proses pembelajaran di Kampus IMWI. Angket diberikan kepada mahasiswa IMWI melalui kuesioner online yang telah dibuat.

\section{HASIL PENELITIAN DAN PEMBAHASAN}

\section{Hasil Penelitian}

\section{Hasil Evaluasi Kualitas Sistem}

Indikator evaluasi Kualitas Sistem E-Learning jika dirata-rata sesuai kriteria (sangat buruk (1), buruk (2), kurang baik (3), baik (4), sangat baik (5)) sebagaimana di bawah ini:

- Jumlah item pertanyaan kuesioner $\quad: 14$

- Jumlah responden $\quad: 100$

- Nilai Minimum $\quad: 1.400$

- Nilai Maksimum $\quad: 7.000$

- Range $\quad: 5.600$

- Rentang : (Range/5) 1.120

- Skor Ideal Kualitas Sistem $\quad: 7.000$

- Skor Aktual Kualitas Sistem $\quad: 5.010$

Rentang Interval Penilaian Aspek Evaluasi Kualitas Sistem

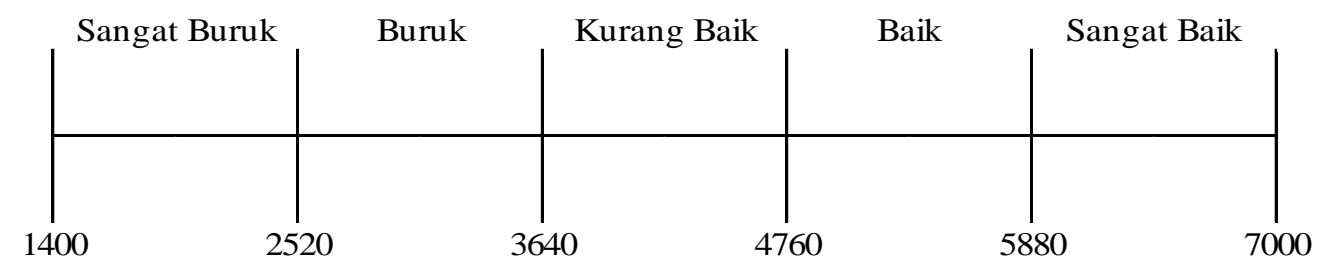

Rata-rata evaluasi Kualitas Sistem mendapat nilai 5.010. Nilai tersebut berada pada rentang inverval 4.760 - 5.880. Hasil tersebut menunjukkan Kualitas Sistem mendapatkan penilaian Baik.

\section{Hasil Evaluasi Kualitas Informasi}

Indikator evaluasi Kualitas Informasi E-Learning jika dirata-rata sesuai kriteria (sangat buruk (1), buruk (2), kurang baik (3), baik (4), sangat baik (5)) sebagaimana di bawah ini:

- Jumlah item pertanyaan kuesioner $\quad: 10$

- Jumlah responden $\quad: 100$

- Nilai Minimum $\quad: 1.000$

- Nilai Maksimum $\quad: 5.000$

- Range $: 4.000$

- Rentang : (Range/5) 800

- Skor Ideal Kualitas Informasi $\quad: 5.000$

- Skor Aktual Kualitas Informasi $\quad: 3.619$ 
Rentang Interval Penilaian Aspek Evaluasi Kualitas Informasi

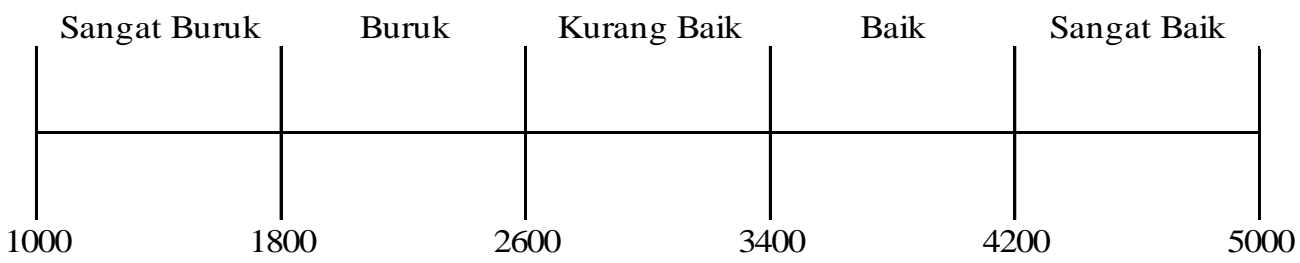

Rata-rata evaluasi Kualitas Informasi mendapat nilai 3.619. Nilai tersebut berada pada rentang inverval 3.400 - 4.200. Hasil tersebut menunjukkan Kualitas Informasi mendapatkan penilaian Baik.

\section{Hasil Evaluasi Kualitas Layanan}

Indikator evaluasi Kualitas Layanan E-Learning jika dirata-rata sesuai kriteria (sangat buruk (1), buruk (2), kurang baik (3), baik (4), sangat baik (5)) sebagaimana di bawah ini:

- Jumlah item pertanyaan kuesioner $\quad: 4$

- Jumlah responden : 100

- Nilai Minimum : 400

- Nilai Maksimum $\quad: 2.000$

- Range $: 1.600$

- Rentang : (Range/5) 320

- Skor Ideal Kualitas Layanan $\quad: 2.000$

- Skor Aktual Kualitas Layanan : 1.344

Rentang Interval Penilaian Aspek Evaluasi Kualitas Layanan

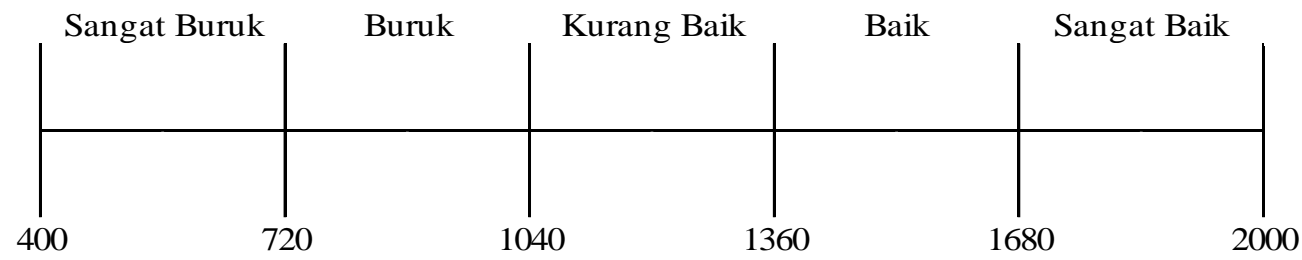

Rata-rata evaluasi Kualitas Layanan mendapat nilai 1.344. Nilai tersebut berada pada rentang inverval 1.040 - 1.360. Hasil tersebut menunjukkan Kualitas Layanan mendapatkan penilaian Kurang Baik.

\section{Hasil Evaluasi Kepuasan Pengguna}

Indikator evaluasi Kepuasan Pengguna jika dirata-rata sesuai kriteria (sangat buruk (1), buruk (2), kurang baik (3), baik (4), sangat baik (5)) sebagaimana di bawah ini:

- Jumlah item pertanyaan kuesioner : : 3

- Jumlah responden : 100

- Nilai Minimum :300

- Nilai Maksimum $\quad: 1.500$

- Range : 1.200

- Rentang : (Range/5) 240

- Skor Ideal Kualitas Layanan $\quad$ : 1.046

- Skor Aktual Kualitas Layanan $\quad: 1.500$ 


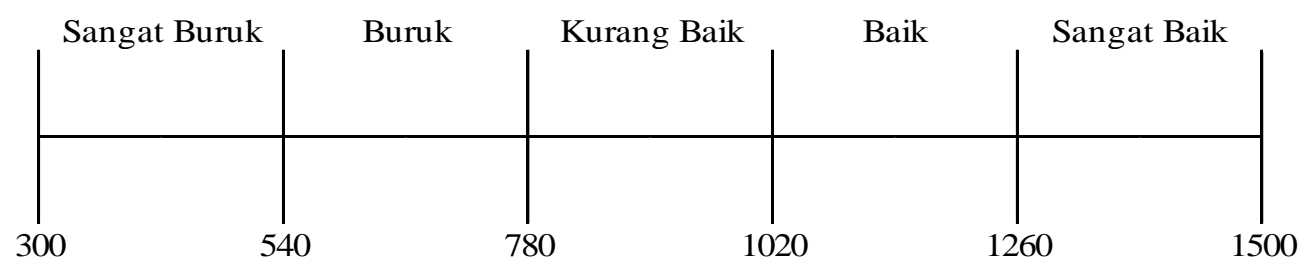

Rata-rata evaluasi Kepuasan Pengguna mendapat nilai 1.046. Nilai tersebut berada pada rentang inverval 1.020 - 1.260. Hasil tersebut menunjukkan Kepuasan Pengguna E-Learning IMWI mendapatkan penilaian Baik.

\section{Pembahasan}

Penelitian ini mengadopsi model kesuksesan sistem informasi DeLone dan McLean, untuk mengevaluasi bagaimana kualitas sistem, kualitas informasi, kualitas layanan, dan kepuasan pengguna dari sistem E-Learning yang dimiliki oleh IMWI.

\section{Pembahasan Evaluasi Kualitas Sistem}

Kualitas sistem dalam sistem informasi E-learning Kampus IMWI menyangkut keterkaitan fitur dalam sistem termasuk performa sistem dan user interface. Dalam penelitian ini, 100 (seratus) orang responden diminta pendapatnya terkait tujuh (tujuh) indikator untuk mengukur kualitas sistem, diantaranya (1) kemudahan pengguna, (2) kemudahan dipelajari, (3) kemudahan akses, (4) keandalan sistem, (5) fleksibilitas, (6) kegunaan fitur, dan (7) keamanan.

Rata-rata hasil evaluasi dari semua indikator kualitas sistem menunjukkan penilaian yang baik. Indikator dengan skor tertinggi adalah kemudahan pengguna: navigasi pada sistem E-Learning IMWI dinilai sederhana dan mudah digunakan. Skor tertinggi kedua pada indikator kemudahan dipelajari. Yang ketiga pada indikator keamanan: pengguna tidak khawatir terhadap keamanan data dan informasi yang tersimpan dalam sistem E-Learning IMWI.

\section{Pembahasan Evaluasi Kualitas Informasi}

Kualitas informasi terkait kualitas output dari sistem informasi, terutama dari bentuk laporan-laporan yang dihasilkan. Adapun indikator yang digunakan untuk mengukur kualitas informasi, diantaranya (1) akurasi, (2) kelengkapan, (3) bentuk, (4) ketepatan waktu, dan (5) relevansi.

Rata-rata hasil evaluasi dari semua indikator kualitas informasi menunjukkan penilaian yang baik. Indikator dengan skor tertinggi adalah bentuk: sistem E-Learning IMWI menyajikan informasi dalam bentuk yang mudah dibaca. Skor tertinggi kedua pada indikator relevansi: informasi yang disajikan sistem $E$-Learning IMWI relevan dengan kebutuhan pengguna. Yang ketiga pada indikator akurasi: sistem $E$ Learning IMWI menyajikan informasi yang akurat.

\section{Pembahasan Evaluasi Kualitas Layanan}

Kualitas layanan terkait kualitas dukungan yang didapatkan pengguna, dalam hal ini layanan dalam pembelajaran E-Learning di Kampus IMWI. Beberapa indikator untuk mengukur kualitas layanan diantaranya: (1) responsiveness (kecepatan respon), (2) technical competence (kemampuan teknik), dan (3) empathy (empati).

Rata-rata hasil evaluasi dari semua indikator kualitas layanan menunjukkan penilaian yang kurang baik. Indikator dengan skor terendah adalah responsiveness (kecepatan respon): operator E-Learning IMWI dinilai memberikan respon yang tidak cepat terhadap permintaan pengguna. Sedangkan di lain sisi, indikator dengan skor tertinggi adalah empathy (empati): operator E-Learning IMWI dinilai memberikan respon yang baik terhadap permintaan pengguna.

\section{Pembahasan Evaluasi Kepuasan Pengguna}

Kepuasan pengguna berkaitan dengan respon dan umpan balik yang dirasakan pengguna setelah melakukan proses pembelajaran secara daring di Kampus IMWI. Indikator yang digunakan untuk mengukur kepuasan pengguna diantaranya: (1) efisiensi, (2) keefektifan, dan (3) kepuasan.

Rata-rata hasil evaluasi dari semua indikator kepuasan pengguna menunjukkan penilaian yang baik. Indikator dengan skor tertinggi adalah kefektifan: sistem E-Learning IMWI dinilai membantu pengguna secara efektif. Skor tertinggi kedua pada indikator kepuasan: kinerja sistem E-Learning IMWI 
memuaskan. Yang ketiga pada indikator efisiensi: sistem E-Learning IMWI dinilai dapat membantu proses pembelajaran daring dengan efisien.

\section{KESIMPULAN}

Berdasarkan hasil pengumpulan data dari para responden dan analisis yang dilakukan ditemukan bahwa: Pertama, Rata-rata evaluasi Kualitas Sistem mendapat nilai 5.010. Nilai tersebut berada pada rentang inverval 4.760 - 5.880. Hasil tersebut menunjukkan Kualitas Sistem mendapatkan penilaian Baik. Sistem E-Learning yang dibangun IMWI sederhana dan mudah digunakan, lalu mudah dipelajari, serta aman. Kedua, Rata-rata evaluasi Kualitas Informasi mendapat nilai 3.619. Nilai tersebut berada pada rentang inverval $3.400-4.200$. Hasil tersebut menunjukkan Kualitas Informasi mendapatkan penilaian Baik. Kualitas informasi E-Learning IMWI baik dalam bentuk yang mudah dibaca, relevan dengan kebutuhan pengguna, dan akurat. Ketiga, Rata-rata evaluasi Kualitas Layanan mendapat nilai 1.344. Nilai tersebut berada pada rentang inverval 1.040 - 1.360. Hasil tersebut menunjukkan Kualitas Layanan mendapatkan penilaian Kurang Baik. Operator E-Learning IMWI dianggap tidak memberikan respon yang cepat terhadap permintaan pengguna, namun di sisi lain operator E-Learning IMWI memberikan respon layanan yang baik. Keempat, Rata-rata evaluasi Kepuasan Pengguna mendapat nilai 1.046. Nilai tersebut berada pada rentang inverval $1.020-1.260$. Hasil tersebut menunjukkan Kepuasan Pengguna $E$ Learning IMWI mendapatkan penilaian Baik. E-Learning IMWI membantu pengguna secara efektif, memuaskan, dan dapat membantu proses pembelajaran daring dengan efisien.

Melalui hasil penelitian ini diharapkan dapat digunakan oleh pihak pengembang E-Learning IMWI atau pihak terkait lainnya untuk melakukan improvement seperlunya terhadap sistem yang telah ada, sehingga lebih baik lagi ke depannya. Sedangkan bagi peneliti berikutnya dapat melanjutkan penelitian terkait penggunaan E-learning ini pada periode-periode berikutnya untuk menguji kemajuan pengembangan E-Learning, ataupun meneliti dengan menggunakan alat uji lain yang lebih beragam dan komprehensif.

\section{DAFTAR PUSTAKA}

Aidah, S. (2019). Pemanfaatan E-Learning sebagai Media Pembelajaran di STIA Al Gazali Barru. Meraja Journal, 2(1), 1-12.

Binus. (2019). E-Learning sebagai Media Pembelajaran Jarak Jauh. Sis.Binus.Ac.Id. https://sis.binus.ac.id/2019/02/13/e-learning-sebagai-media-pembelajaran-jarak-jauh/

Delone, W. H., \& McLean, E. R. (2003). The DeLone and McLean Model of Information Systems Success: a Ten-Year Update. Journal of Management Information Systems, 19(4), 9-30.

Hartanto, W. (2016). Penggunaan E-Learning Sebagai Media Pembelajaran. Jurnal Pendidikan Ekonomi: Jurnal Ilmiah Ilmu Pendidikan, Ilmu Ekonomi Dan Ilmu Sosial, 10(1).

Iivari, J. (2005). An Empirical Test of the DeLone-McLean Model of Information System Success. ACM SIGMIS Database: The DATABASE for Advances in Information Systems, 36(2), 8-27.

Purwandari, R. (2016). Evaluasi Penggunaan E-Learning pada Proses Pembelajaran Program Studi Pendidikan Teknik Mesin Universitas Sebelas Maret. UNS (Sebelas Maret University).

Urbach, N., \& Müller, B. (2012). The Updated DeLone and McLean Model of Information Systems Success. In Information systems theory (pp. 1-18). Springer.

Wiyata, M. T., \& Awaliah, N. N. (2019). Pengaruh Budaya dan Kepercayaan Merek Terhadap Pengambilan Keputusan Mahasiswa Memilih Kuliah di Institut Manajemen Wiyata Indonesia. Cakrawala, 2(1), 32-46. 
82 ARIKA, Agustus 2020 